MATEC Web of Conferences 33, 06004 (2015)

DOI: $10.1051 /$ matecconf/ 20153306004

(C) Owned by the authors, published by EDP Sciences, 2015

\title{
Martensitic transformation and shape memory effect in Ni-Al based alloys
}

\author{
Svitlana Ponomarova ${ }^{1, a}$, Valerii Odnosum ${ }^{1}$, lurii Koval ${ }^{1}$, Gennady Monastyrsky², Viktor Kolomytsev ${ }^{1}$, P. Ochin ${ }^{3}$, R. Portier $^{3}$ \\ Tomasz Czeppe ${ }^{4}$ and Oleksandr Ponomarov ${ }^{5}$ \\ ${ }^{1}$ G.V. Kurdyumov Institute for Metal Physics N.A.S. of Ukraine, 36 Academician Vernadsky blvd., Kiev 03680, Ukraine \\ ${ }^{2}$ Kiev National University "KPI", 37 Prospect Peremogy, Kiev 03056, Ukraine \\ 3 de l'Ecole Nationale Supérieure de Chimie de Paris 11, rue Pierre et Marie Curie - 75231 Paris Cedex 05, France \\ ${ }^{4}$ Institute of Metallurgy and Materials Sciences PAS, 25 Reymonta Str., 30-059 Krakow, Poland \\ ${ }^{5}$ Intro-Pro LLC, 3a Grishko, Kiev 02140, Ukraine
}

\begin{abstract}
Ni-Al based alloys are considered to be attractive high temperature shape memory materials. Among proposed alloying in the present work, there are $\mathrm{Fe}, \mathrm{Zr}$ and $\mathrm{Co}$ elements. High temperature of martensitic transformation (Ms $>150{ }^{0} \mathrm{C}$ ) with full shape recovery is achieved due to $\mathrm{Zr}$ alloying. Complex doping of $\mathrm{Zr}$ and $\mathrm{Fe} / \mathrm{Co}$ also makes possible to produce perspective high temperature shape memory alloys.
\end{abstract}

\section{Introduction}

Binary Ni-Al alloys undergo thermoelastic martensitic transformation (MT) $[1,2,3]$ in temperature range of 0 $900^{\circ} \mathrm{C}$ depending on nickel content. According to $[3,4]$ they may be considered as a potentially high temperature shape memory alloys.

Ni-rich $\beta \mathrm{Ni}-\mathrm{Al}$ alloys are promising materials for technical usage due to their high melting temperature, excellent oxidation resistance and advantageous heat conductivity [1]. One of the applications is to produce high-strength structural alloys for use at temperatures higher than possible presently in the case of conventional titanium and nickel based alloys [5]. Another possibility is $\mathrm{Ni}-\mathrm{Al}$ based coatings with improved high temperature strength and service lifetime of devices [6].

Main drawbacks of Ni-Al alloys are both lack of ductility at low temperatures and poor strength at high temperatures $[1,5]$.

As well known, widely used way for changing material properties is alloying. Composition of alloy determines martensitic transformation temperatures. Detailed analyze of doping elements [1-3,5] showed that it is possible to get $\mathrm{Ni}-\mathrm{Al}$ based alloys with shape recovery at temperatures higher than $100^{\circ} \mathrm{C}$.

To reach this aim we have chosen two criteria of selection doping elements for $\mathrm{Ni}-\mathrm{Al}$ alloys:

$\checkmark$ the element shouldn't reduce martensitic transformation;

$\checkmark \quad$ it should to improve room temperature ductility of the alloy.

For the binary Ni-Al alloys in concentration range of (60-69) at.\% of $\mathrm{Ni} \mathrm{Ms}$ temperature depends on alloy composition as follows: $\mathrm{Ms}=(124 \mathrm{Ni}-7410) \mathrm{K}$ [2]. Nickel content increases MT temperatures in binary alloys.
A lot of doping elements (Co, Ni, Pd, Pt, Cu, Ag, Au [7-10]) promote rising start temperatures of martensitic transformation in Ni-Al alloys.

Platinum group of metals ( $\mathrm{Pt}, \mathrm{Rh}, \mathrm{Ir}, \mathrm{Pd}$ ) is used as doping elements for manufacturing $\mathrm{Ni}-\mathrm{Al}$ based coatings in order to improve strength, oxidation resistance, TBC adhesion and service lifetime of materials. Alloying with Pt doesn't depress martensitic transformation [3, 11].

Gallium makes better of Ni-Al ductility by changing stacking fault energies and leads to the deterioration of slip interface plane brittle cleavage [12, 13].

From the point of view of ductilization the best result was achieved due to Fe alloying [7]. This element promotes formation of the second phase with better ductile properties. However, at the same time $\mathrm{Fe}$ significantly decreases MT temperatures.

Influence of zirconia on the temperature range of martensitic transformation of $\mathrm{Ni}_{64} \mathrm{Al}_{36} \mathrm{Zr}_{\mathrm{x}}$ alloys (0.370.77 at.\% Zr) has been studied in [14]. As was established, these alloys undergo transformation below room temperature. According to [15] $\mathrm{Zr}$ doping also leads to the formation of new phase and zirconia was observed to segregate on dislocations. This result supports the suggestion that the substantial increase in ductile-tobrittle transition temperature in $\mathrm{Ni}-\mathrm{Al}-\mathrm{Zr}$ alloys is caused by the pinning of dislocations by zirconium. However, it is difficult to conclude about mechanical properties of the materials obtained because mechanical tests were not provided in [14].

In the present work the Ni-Al-Zr, Ni-Al- $(\mathrm{Zr}+\mathrm{Co})$, Ni$\mathrm{Al}-\mathrm{Fe}$, and $\mathrm{Ni}-\mathrm{Al}-(\mathrm{Fe}+\mathrm{Zr})$ alloys were studied with the $\mathrm{Ni}_{65} \mathrm{Al}$ and $\mathrm{Ni}_{60} \mathrm{Fe}_{3} \mathrm{Al}$ base compositions in order to investigate the influence of $\mathrm{Zr}, \mathrm{Fe}$ and complex doping on the martensitic parameters.

\footnotetext{
${ }^{a}$ Corresponding author: sveta.ponomaryova@gmail.com
} 


\section{Experimental procedures}

Bulk Ni-Al, Ni-Al-X (Zr, Zr+Co, Zr+Fe) alloys (Table 1) were produced from pure elements by arc melting under argon atmosphere. For homogenization the materials were remelted seven times. Next, the heat treatment was carried out by quenching from $1200^{\circ} \mathrm{C}$ into room temperature water during 15 minutes.

Table 1. Alloys compositions.

\begin{tabular}{|c|c|}
\hline $\begin{array}{c}\text { Alloy composition, } \\
\text { at.\% }\end{array}$ & $\begin{array}{c}\text { Ni/Al } \\
\text { ratio }\end{array}$ \\
\hline $\mathrm{Ni}_{64.8} \mathrm{Al}_{35.2}$ & 1.84 \\
\hline $\mathrm{Ni}_{64.5} \mathrm{Al}_{34.5} \mathrm{Zr}_{1}$ & 1.87 \\
\hline $\mathrm{Ni}_{65.1} \mathrm{Al}_{32.4} \mathrm{Zr}_{2.5}$ & 2.00 \\
\hline $\mathrm{Ni}_{63.5} \mathrm{Al}_{33.6} \mathrm{Zr}_{2.9}$ & 1.89 \\
\hline $\mathrm{Ni}_{66.4} \mathrm{Al}_{30.6} \mathrm{Zr}_{3}$ & 2.17 \\
\hline $\mathrm{Ni}_{64.7} \mathrm{Al}_{31.7} \mathrm{Zr}_{3.6}$ & 2.04 \\
\hline $\mathrm{Ni}_{66.2} \mathrm{Al}_{29.8} \mathrm{Zr}_{4}$ & 2.22 \\
\hline $\mathrm{Ni}_{59.8} \mathrm{Al}_{37.4} \mathrm{Fe}_{2.8}$ & 1.60 \\
\hline $\mathrm{Ni}_{54.9} \mathrm{Al}_{39.7} \mathrm{Fe}_{4.5} \mathrm{Zr}_{0.9}$ & 1.38 \\
\hline $\mathrm{Ni}_{64} \mathrm{Al}_{30} \mathrm{Zr}_{3} \mathrm{Co}_{3}$ & 2.13 \\
\hline
\end{tabular}

Investigations of MT parameters by electrical resistivity method and three-point bending shape recovery test have been performed at temperature range of $-196+600^{\circ} \mathrm{C}$. The accuracy of temperature measurements of these methods is $\pm 5^{0} \mathrm{C}$.

Shape recovery $\left(\mathrm{K}_{\mathrm{sme}}\right)$ is accessed by the ratio between the recovered strain observed after heating to the total strain at MT using three point bending test data (in percent).

Structural and microstructural investigations were also performed after mentioned heat treatment. The phase composition was analyzed by DRON 3M diffractometer with $\mathrm{Cu}-\mathrm{K} \alpha$ radiation. Microstructure analysis was done using light microscope Axiovert 40 MAT. The specimens were mechanically prepared and etched with Coparella's reagent $(5 \mathrm{~g}$ ferric chloride, $2 \mathrm{ml} \mathrm{HCl}, 99 \mathrm{ml}$ ethyl alcohol).

\section{Results and discussion}

\subsection{Parameters of martensitic transformation}

In the following section the influence of different alloying elements on the characteristic temperatures of martensitic transformation and shape memory effect in $\mathrm{Ni}-\mathrm{Al}$ based alloys will be discussed.
The characteristic temperatures of MT (Ms, Mf, As, Af) were measured by electrical resistivity method and three point bending shape recovery test.

Binary $\mathrm{Ni}_{64.8} \mathrm{Al}_{35.2}$ undergoes $\mathrm{MT}$ with complete shape recovery at high temperatures: $\mathrm{Ms}=200^{\circ} \mathrm{C}$, $\mathrm{As}=130^{\circ} \mathrm{C}$ (Fig. 1, Table 2). Analyze of tendencies in MT temperatures for binary $\mathrm{Ni}-\mathrm{Al}$ alloys $[3,7,14]$ and our own results show that the increase of $\mathrm{Ni}$ content causes Ms to rise, while the addition of third element may act in two different directions. Additions of $\mathrm{Ti}, \mathrm{V}, \mathrm{Cr}$, $\mathrm{Mn}, \mathrm{Fe}, \mathrm{Zr}, \mathrm{Nb}, \mathrm{Mo}, \mathrm{Ta}, \mathrm{W}$, and Si stabilize the parent $\beta$ phase, thereby lowering the Ms temperature, while additions of $\mathrm{Co}, \mathrm{Cu}$, or $\mathrm{Ag}$ destabilize the $\beta$ phase, increasing Ms temperature.

Table 2. Characteristic temperatures of martensitic transformation and shape memory effect in Ni-Al based alloys.

\begin{tabular}{|c|c|c|c|c|c|}
\hline $\begin{array}{c}\text { Alloy composition, } \\
\text { at. \% }\end{array}$ & $\begin{array}{c}\mathbf{M}_{\mathbf{s},}, \\
{ }^{\mathbf{0}} \mathbf{C}\end{array}$ & $\begin{array}{c}\mathbf{M}_{\mathbf{f}} \mathbf{C} \\
{ }^{\mathbf{C}}\end{array}$ & $\begin{array}{c}\mathbf{A s}, \\
{ }^{\mathbf{0}} \mathbf{C}\end{array}$ & $\begin{array}{c}\mathbf{A f}, \\
{ }^{\mathbf{0}} \mathbf{C}\end{array}$ & $\begin{array}{c}\mathbf{K}_{\text {sme, }} \\
\mathbf{\%}\end{array}$ \\
\hline $\mathrm{Ni}_{64.8} \mathrm{Al}_{35.2}$ & 200 & 100 & 130 & 275 & 100 \\
\hline $\mathrm{Ni}_{64.5} \mathrm{Al}_{34.5} \mathrm{Zr}_{1}$ & -125 & - & - & -120 & \\
\hline $\mathrm{Ni}_{65.1} \mathrm{Al}_{32.4} \mathrm{Zr}_{2.5}$ & 210 & 175 & 225 & 265 & 100 \\
\hline $\mathrm{Ni}_{63.5} \mathrm{Al}_{33.6} \mathrm{Zr}_{2.9}$ & 150 & 20 & 125 & 225 & 100 \\
\hline $\mathrm{Ni}_{66.4} \mathrm{Al}_{30.6} \mathrm{Zr}_{3}$ & 150 & 20 & 30 & 170 & 100 \\
\hline $\mathrm{Ni}_{64.7} \mathrm{Al}_{31.7} \mathrm{Zr}_{3.6}$ & 190 & 125 & 175 & 225 & 100 \\
\hline $\mathrm{Ni}_{66.2} \mathrm{Al}_{29.8} \mathrm{Zr}_{4}$ & 0 & -110 & -70 & 10 & 100 \\
\hline $\mathrm{Ni}_{59.8} \mathrm{Al}_{37.4} \mathrm{Fe}_{2.8}$ & 200 & 100 & 115 & 230 & 100 \\
\hline $\mathrm{Ni}_{54.9} \mathrm{Al}_{39.7} \mathrm{Fe}_{4.5} \mathrm{Zr}_{0.9}$ & -100 & - & - & -90 & 100 \\
\hline $\mathrm{Ni}_{64} \mathrm{Al}_{30} \mathrm{Zr}_{3} \mathrm{Co}_{3}$ & 190 & 135 & 160 & 220 & 100 \\
\hline
\end{tabular}

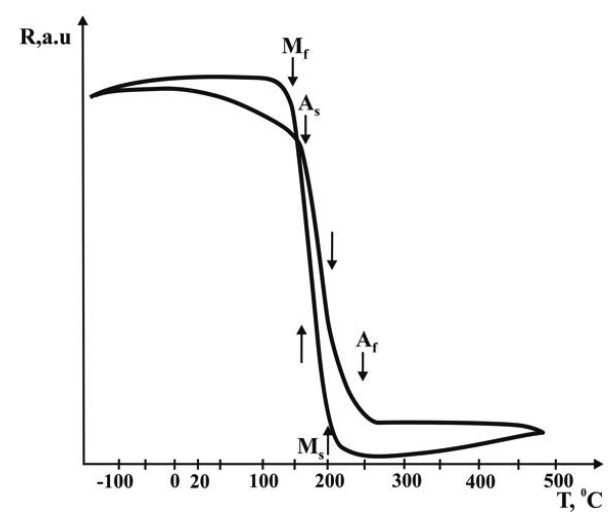

Fig.1. Temperature dependence of electrical resistance for the $\mathrm{Ni}_{64.8} \mathrm{Al}_{35.2}$ alloy.

Nonlinear behavior of MT temperatures was observed as a result of zirconia alloying. Even small addition of $\mathrm{Zr}$ (1 at.\%) significantly shifts characteristic transformation temperatures to lower temperature region up to $\mathrm{Ms}=$ 
$-125^{\circ} \mathrm{C}$, in comparison with the binary alloy (Fig. 2). However another difference with the binary alloy is weak shape memory effect in $\mathrm{Ni}_{64.5} \mathrm{Al}_{34.5} \mathrm{Zr}_{1}$.

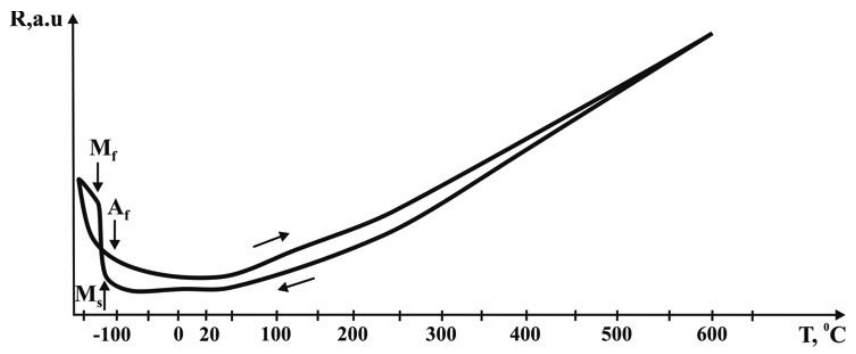

Fig. 2. Temperature dependence of electrical resistance for the $\mathrm{Ni}_{64.5} \mathrm{Al}_{34.5} \mathrm{Zr}_{1}$ alloy.

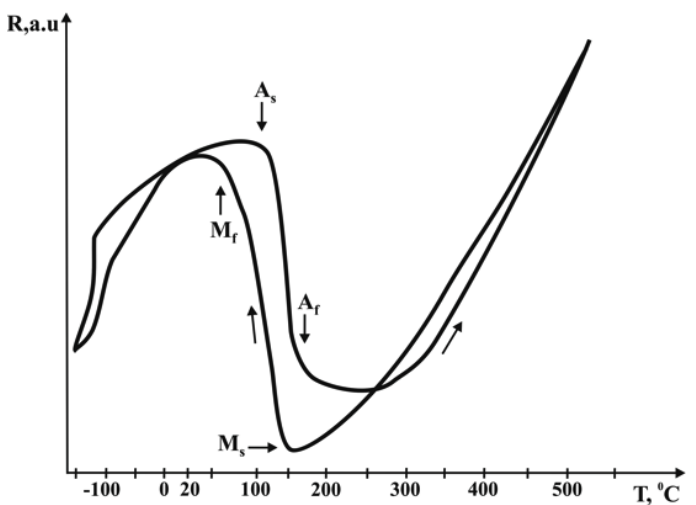

Fig. 3. Temperature dependence of electrical resistance for the $\mathrm{Ni}_{63.5} \mathrm{Al}_{33.6} \mathrm{Zr}_{2.9}$ alloy.

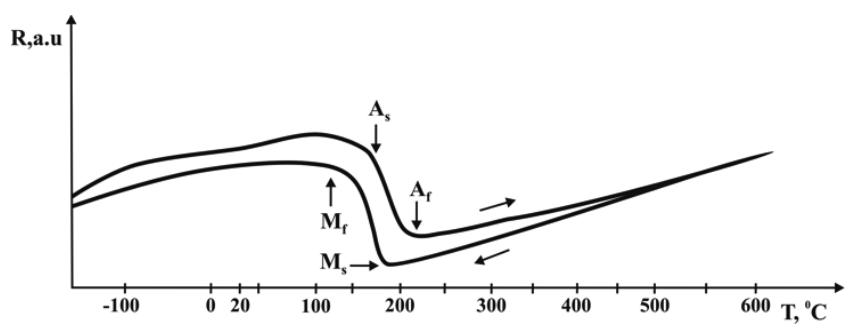

Fig. 4. Temperature dependence of electrical resistance for the $\mathrm{Ni}_{64.7} \mathrm{Al}_{31.7} \mathrm{Zr}_{3.6}$ alloy.

As was shown in work [14], additions of (0.37-0.77) at. $\% \mathrm{Zr}$ lead to decrease of $\mathrm{Ms}$ temperature below room temperature. This tendency correlates with our results. However, in work [14] another base composition of binary alloy $\left(\mathrm{Ni}_{64} \mathrm{Al}_{36}\right.$ with $\left.\mathrm{Ni} / \mathrm{Al}=1.78\right)$ was used in comparison with ours $\left(\mathrm{Ni}_{64.8} \mathrm{Al}_{35.2}\right.$ with $\left.\mathrm{Ni} / \mathrm{Al}=1.84\right)$.

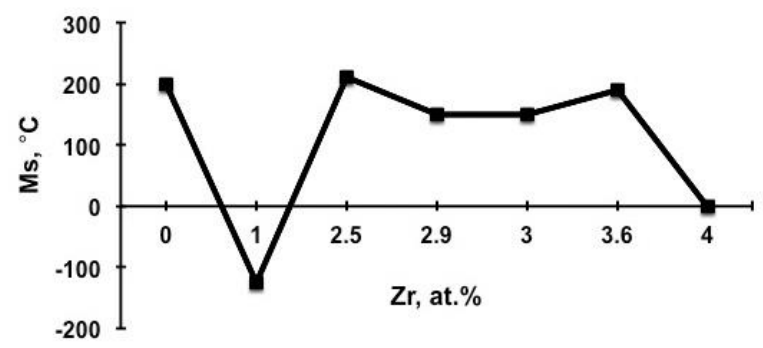

Fig. 5. Ms dependence from $\mathrm{Zr}$ content in $\mathrm{Ni}-\mathrm{Al}-\mathrm{Zr}$ alloys.
Tendency of Ms and As to rise with further increase of $\mathrm{Zr}$ content is noticed (Table 2, Fig. 5). For example, $\mathrm{Ni}_{63.5} \mathrm{Al}_{33.6} \mathrm{Zr}_{2.9}$ and $\mathrm{Ni}_{66.4} \mathrm{Al}_{30.6} \mathrm{Zr}_{3}$ alloys undergo martensitic transformation at $\mathrm{Ms}=150^{\circ} \mathrm{C}$, lower temperature than in case of binary $\mathrm{Ni}_{64.8} \mathrm{Al}_{35.2}$ alloy $\left(\mathrm{Ms}=200^{\circ} \mathrm{C}\right)$.

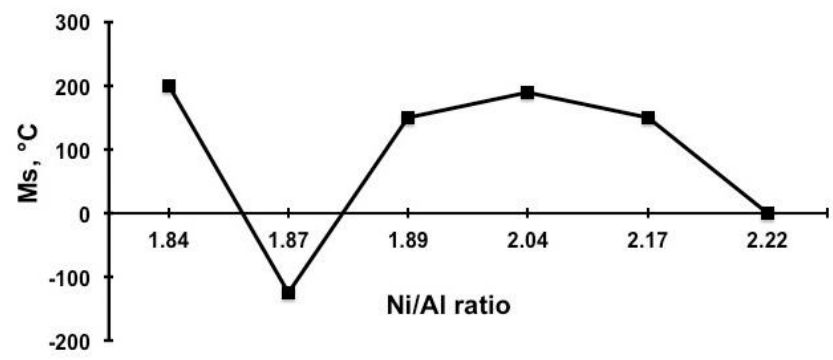

Fig. 6. Ms dependence on the Ni/Al ratio in Ni-Al-Zr alloys.

The important factor controlling characteristic temperatures of $\mathrm{MT}$ is also $\mathrm{Ni} / \mathrm{Al}$ ratio in $\mathrm{Ni}-\mathrm{Al}$ based alloys. As shown in Figs. 5, 6, Ms significantly decreases with small $\mathrm{Zr}$ additions but together with the increasing of $\mathrm{Ni} / \mathrm{Al}$ ratio. Rising of $\mathrm{Ni} / \mathrm{Al}$ ratio (to 2.17) as well as $\mathrm{Zr}$ content (up to 3.6 at.\%) promotes increasing of MT temperatures. However, further rising of these parameters shows the tendency to lower MT temperatures.

Interesting fact is that increasing $\mathrm{Ni} / \mathrm{Al}$ ratio from 1.84 for $\mathrm{Ni}_{63.5} \mathrm{Al}_{33.6} \mathrm{Zr}_{2.9}$ to 2.16 for $\mathrm{Ni}_{66.4} \mathrm{Al}_{30.6} \mathrm{Zr}_{3}$ compositions, preserving fixed $\mathrm{Zr}$ content decreases As by $100^{\circ} \mathrm{C}$ (from 125 to $30^{\circ} \mathrm{C}$, Table 2 ).

As shown in Table $1, \mathrm{Ni}_{64.8} \mathrm{Al}_{35.2}, \mathrm{Ni}_{64.5} \mathrm{Al}_{34.5} \mathrm{Zr}_{1}$, and $\mathrm{Ni}_{63.5} \mathrm{Al}_{33.6} \mathrm{Zr}_{2.9}$ alloys have the same $\mathrm{Ni} / \mathrm{Al}$ ratio (1.841.87). However, their characteristic temperatures of MT are completely different. The first alloy is binary one with $\mathrm{Ms}=200^{\circ} \mathrm{C}$. Small zirconia addition lowers Ms to $-125^{\circ} \mathrm{C}$, but further increasing of $\mathrm{Zr}$ content increases $\mathrm{Ms}$ to $150^{\circ} \mathrm{C}$. In this example the "pure" zirconia influence on MT temperatures is clearly seen.

As established, all considered Ni-Al-Zr alloys with $>1$. at. $\% \mathrm{Zr}$ demonstrate full shape memory effect $\left(\mathrm{K}_{\mathrm{sme}}=\right.$ $100 \%$, Table 2).

Small addition of $\mathrm{Zr}$ decreases MT temperatures. This tendency may be reversed due to the increase of $\mathrm{Ni} / \mathrm{Al}$ ratio. Consequently, it may be concluded that in the case of small $\mathrm{Zr}$ additions (2.5-3.5 at.\% $\mathrm{Zr}$ ) it was possible to achieve high MT temperature, with $\mathrm{Ms} 210^{\circ} \mathrm{C}$ in a result of both controlling factors $\mathrm{Zr}$ content and $\mathrm{Ni} / \mathrm{Al}$ ratio close to 2 properly chosen.

Replacing $\mathrm{Ni}$ by $\mathrm{Fe}$ in $\mathrm{Ni}_{59.8} \mathrm{Al}_{37.4} \mathrm{Fe}_{2.8}$ alloy doesn't change MT temperature range in comparison with the binary $\mathrm{Ni}_{64.8} \mathrm{Al}_{35.2}$. This alloy reveals complete shape recovery. However, increase of the $\mathrm{Fe}$ content together with small $\mathrm{Zr}$ addition (0.9 at.\%) caused significant shift of MT temperatures to the lower temperature range (Table 2).

Complex alloying with $\mathrm{Zr}$ and Co only slightly decreased MT parameters and kept complete shape recovery in case of investigated alloy composition (Table 2). 
3.2 Structure and microstructure investigations of $\mathrm{Ni}$ - $\mathrm{Al}$ based alloys.

The structural analysis of $\mathrm{Ni}-\mathrm{Al}$ and $\mathrm{Ni}-\mathrm{Al}$ based alloys has been performed at room temperature.

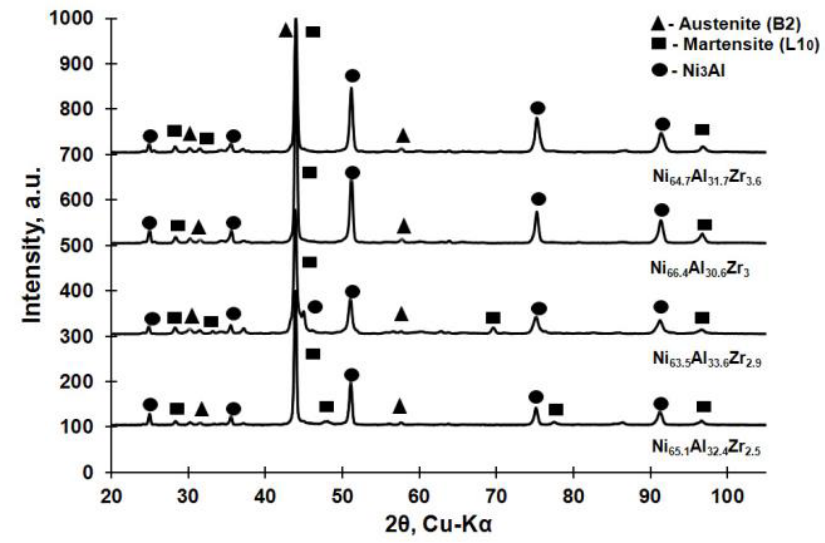

Fig. 7. X-ray diffraction pattern for Ni-Al-Zr alloys.

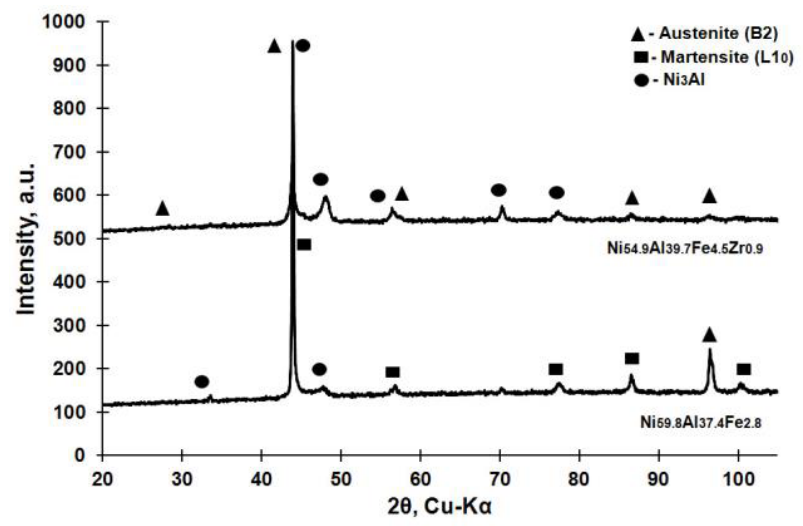

Fig. 8. X-ray diffraction pattern for Ni-Al-Fe, Ni-Al-Fe-Zr alloys.

Binary alloy contains $\mathrm{B} 2$ parent phase, $\mathrm{Ni}_{3} \mathrm{Al}(\gamma)$ and $\mathrm{L} 1_{0}$ type ordered martensite as well as Ni-Al-Zr ones (Fig. 7).

Iron doping and complex alloying by $\mathrm{Co}$ and $\mathrm{Zr}$ ( $\mathrm{Ni}_{59.8} \mathrm{Al}_{37.4} \mathrm{Fe}_{2.8}$ and $\mathrm{Ni}_{64} \mathrm{Al}_{30} \mathrm{Zr}_{3} \mathrm{Co}_{3}$, Fig. 8) doesn't show changes in quantitate phase composition comparing with binary alloy. However, only $\mathrm{B} 2$ and $\mathrm{Ni}_{3} \mathrm{Al}(\gamma)$ phases are presented at room temperature in Ni-Al-Zr-Fe alloy.

$\mathrm{Ni}-\mathrm{Al}$ alloys are known from its brittleness. Elements like $\mathrm{Zr}, \mathrm{Co}, \mathrm{Zr}+\mathrm{Co}$, and $\mathrm{Zr}+\mathrm{Fe}$ are potentially perspective-additions for the rain refinement.

Microstructural investigations show that large grains in binary $\mathrm{Ni}-\mathrm{Al}$ alloy (Table 3 ) are reduced after zirconia alloying (Table 3, Fig. 10). Accordingly with the estimated average grain sizes for different alloys, the refinement increases with increasing $\mathrm{Zr}$ content in alloy. For maximum $\mathrm{Zr}$ content (4 at.\%) grains dimensions were eight times reduced. So, addition of $\mathrm{Zr}$ (more than 1 at.\%) leads to decrease grain size of conventionally casting alloys and $\mathrm{Zr}$ seems to be good candidate for the production of the rapidly quenched Ni-Al-Zr alloys.

As was reported in [16], Ni-Al-X ribbons with X: Co, $\mathrm{Cu}, \mathrm{Cr}, \mathrm{Zr}, \mathrm{Co}+\mathrm{Zr}$ were produced. As it was found, Ni$\mathrm{Al}-\mathrm{Zr}$ and $\mathrm{Ni}-\mathrm{Al}-(\mathrm{Co}+\mathrm{Zr})$ ribbons were of the best quality. Other alloying elements caused poor quality of the ribbons with pores or flakes.

Table 3. Average grain sizes of $\mathrm{Ni}-\mathrm{Al}$ based alloys.

\begin{tabular}{|c|c|c|}
\hline $\begin{array}{c}\text { Alloy } \\
\text { composition, } \\
\text { at.\% }\end{array}$ & $\begin{array}{c}\text { Lengthwise } \\
\text { size }\end{array}$ & $\begin{array}{c}\text { Cross out } \\
\text { size }\end{array}$ \\
\hline $\mathrm{Ni}_{64.8} \mathrm{Al}_{35.2}$ & 488.8 & 205.4 \\
\hline $\mathrm{Ni}_{64.5} \mathrm{Al}_{34.5} \mathrm{Zr}_{1}$ & 187.7 & 57.4 \\
\hline $\mathrm{Ni}_{65.1} \mathrm{Al}_{32.4} \mathrm{Zr}_{2.5}$ & 78.2 & 22.3 \\
\hline $\mathrm{Ni}_{63.5} \mathrm{Al}_{33.6} \mathrm{Zr}_{2.9}$ & 72.3 & 15.1 \\
\hline $\mathrm{Ni}_{66.4} \mathrm{Al}_{30.6} \mathrm{Zr}_{3}$ & 66.8 & 16.9 \\
\hline $\mathrm{Ni}_{64.7} \mathrm{Al}_{31.7} \mathrm{Zr}_{3.6}$ & 61.1 & 16.3 \\
\hline $\mathrm{Ni}_{66.2} \mathrm{Al}_{29.8} \mathrm{Zr}_{4}$ & 57.9 & 283 \\
\hline $\mathrm{Ni}_{59.8} \mathrm{Al}_{37.4} \mathrm{Fe}_{2.8}$ & 517.2 & 103.9 \\
\hline $\mathrm{Ni}_{54.9} \mathrm{Al}_{39.7} \mathrm{Fe}_{4.5}$ & 208.1 & 10.5 \\
\hline $\mathrm{Zr}_{0.9}$ & & \\
\hline $\mathrm{Ni}_{64} \mathrm{Al}_{30} \mathrm{Zr}_{3} \mathrm{Co}_{3}$ & 23.9 & \\
\hline
\end{tabular}

Martensitic relief is seen in binary $\mathrm{Ni}_{64.8} \mathrm{Al}_{35.2}$ (Fig. 9) and $\mathrm{Ni}_{59.8} \mathrm{Al}_{37.4} \mathrm{Fe}_{2.8}$ after heat treatment (Fig. 11) at room temperature. In both cases average grain size is quite large. It becomes clear that $\mathrm{Fe}$ is not acting as grains refiner.

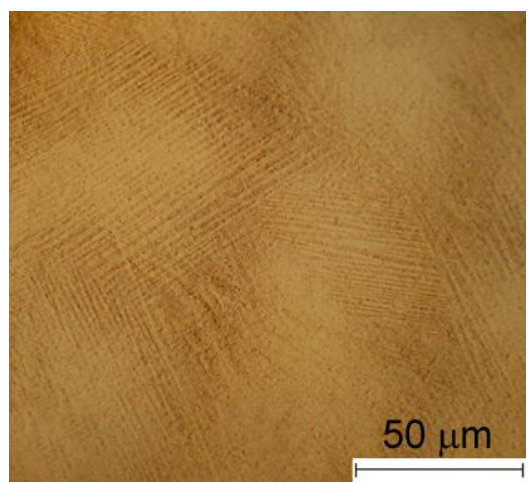

Fig 9. Microstructure the $\mathrm{Ni}_{64.8} \mathrm{Al}_{35.2}$ alloy.

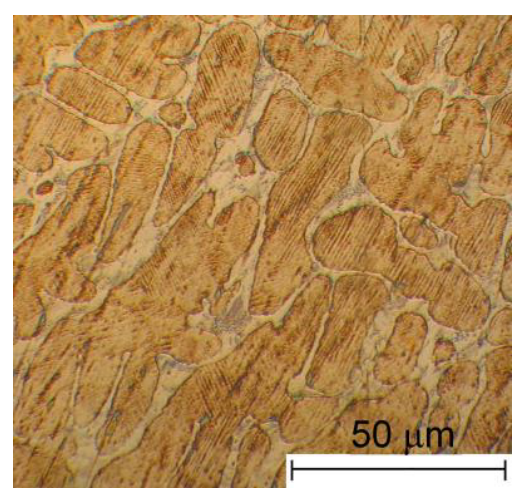

Fig.10. Microstructure of the $\mathrm{Ni}_{66.4} \mathrm{Al}_{30.6} \mathrm{Zr}_{3}$ alloy. 


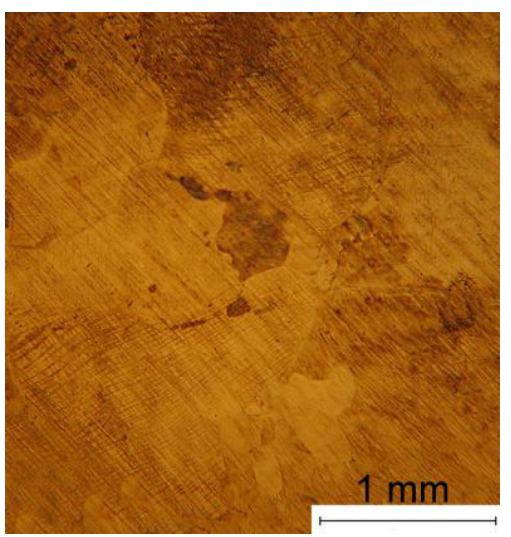

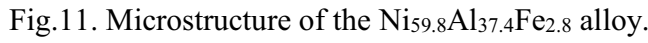

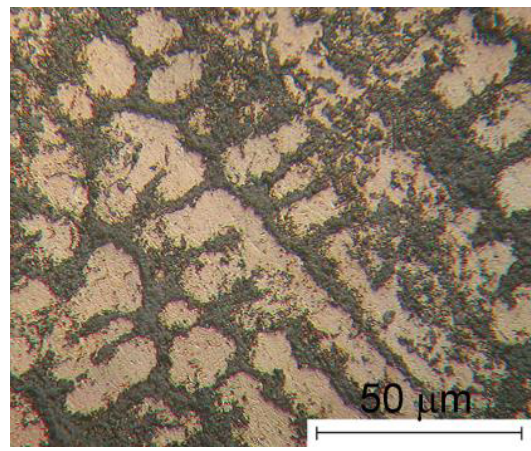

Fig. 12 Microstructure of the $\mathrm{Ni}_{64} \mathrm{Al}_{30} \mathrm{Zr}_{3} \mathrm{Co}_{3}$ alloy.

\section{Conclusions}

Analyze of influence of different alloying $(\mathrm{Zr}, \mathrm{Fe}, \mathrm{Zr}+\mathrm{Fe}$, $\mathrm{Zr}+\mathrm{Co}$ ) on martensitic parameters in $\mathrm{Ni}-\mathrm{Al}$ alloys from point of view of producing high temperature shape memory alloys with small gain size has been performed.

$\checkmark$ All considered doping elements do not depress martensitic transformation.

$\checkmark \quad \mathrm{Zr}$ doping of $\mathrm{Ni}-\mathrm{Al}$ alloys as well as $\mathrm{Zr}+\mathrm{Fe}$ and $\mathrm{Zr}+\mathrm{Co}$ significantly decreases grain sizes in $\mathrm{Ni}$ Al based alloys.

$\checkmark$ Ni-Al-Fe $\quad\left(\mathrm{Ni}_{59.8} \mathrm{Al}_{37.4} \mathrm{Fe}_{2.8}\right), \quad \mathrm{Ni}-\mathrm{Al}-\mathrm{Zr}$ $\left(\mathrm{Ni}_{65.1} \mathrm{Al}_{32.4} \mathrm{Zr}_{2.5}, \mathrm{Ni}_{64.7} \mathrm{Al}_{31.7} \mathrm{Zr}_{3.6}\right)$ and $\mathrm{Ni}-\mathrm{Al}-\mathrm{Zr}-$ Co $\left(\mathrm{Ni}_{64} \mathrm{Al}_{30} \mathrm{Zr}_{3} \mathrm{Co}_{3}\right)$ demonstrate high temperature shape memory effect.

$\checkmark$ Increasing of $\mathrm{Zr}$ content causes of the same influence on martensitic start temperatures (Ms, As) as increasing $\mathrm{Ni} / \mathrm{Al}$ ratio.

$\checkmark \mathrm{Zr}$ as well as $(\mathrm{Zr}+\mathrm{Co})$ and $(\mathrm{Fe}+\mathrm{Zr})$ are perspective alloying elements for producing alloys by rapid solidification methods.

\section{References}

1. D. B. Miracle, Acta Metal. Mater. 41, 648 (1993)

2. J. L. Smialek, R. Hebeman, NASA TM X-2654, 1 (1972)

3. Y. K. Au, C.M.Wayman, Scripta Metall. 6, 1209 (1972)
4. Y. D Kim, C. M. Wayman, Scripta Metall. 24, 245 (1990)

5. R. Darolia, JOM 43, 44 (1991)

6. R. R. Adharapurara, J. Zhu, V. S. Dheeradhada, D.M. Lipkin, T. M. Pollock, (www.science.gov/topicpages $/ \mathrm{m} / \mathrm{mo}+$ base+alloys.ht $\mathrm{ml})$

7. E. P. George C. T. Liu, J. A. Horton C. J. Sparks M. Kao, H. Kunsmann, T. King, Mater. Charact. 32, 139 (1994)

8. Raghavendra R. Adharapurapua and el. (manuscript)

9. R. J. Thompson, J. C. Zhao, R. J. Hemker, Intermetallics 18, 792 (2010)

10. S. M. Kim, M. H. Oh, D. M. Wee, Metall. Mater. Trans. A 34, 2089 (2003)

11. G.E. Monastyrsky, P. Ochin, V.V. Odnosum, A. Yu. Pasko, V.I. Kolomytsev, Yu.N. Koval, Mater. Sci. Forum 738-739, 506 (2013)

12. Yu. M. Koval, G. E. Monastyrsky, V. V. Odnosum, G. S. Firstov, J. van Humbeeck, J. Phys. IV France 1121063 (2003)

13. P. Lazar, P. Podloucky, Phys. Rev. B 73, 104114 (2006)

14. R. Kainuma, H. Otani, K. Ishida, Metall. Mater. Trans. A, 27, 2445 (1996)

15. R. Jayaram, M.K. Miller, Scripta Metall. Mater., 33, $19,(1995)$

16. Yu. M. Koval, G. E. Monastyrsky, V. I. Kolomytsev, V. V. Odnosum, P. Oshin, T. Czeppe, Metallofiz. Noveishie Tekhnol. 34, 855 (2012) 
